\title{
Characteristics and origin of a Saalian glaciolacustrine to glaciofluvial succession in the Hümmling region, NW Germany
}

\author{
JACQUES SCHWAN* \& CORNELIS KASSE*
}

\author{
Geestplatten, Glaciolacustrine deposits, Saalian glaciation
}

\begin{abstract}
In the lowlands of northwest Germany, glaciofluvial plateaus (German: Geestplatten), and pushmoraines built up by the Saalian ice sheet are surrounded by flat and low-lying country. In the study area in the Hümmling, the Geestplatte consists of mainly sandy meltwater deposits with a capping of groundmoraine or till residue. This outwash plain was built up during the Main Drenthe Advance of the Saalian glaciation and subsequently overridden by the expanding ice sheet. The meltwater deposits form coarsening-upward sequences exposed in three sandpits in the study area.

From base to top in the exposures, three waterlaid facies are distinguished: a basal glaciolacustrine facies, a transitional facies and an upper glaciofluvial facies. Unless erosion has interfered, the upward change from one facies to the next is markedly gradational.

The paper gives arguments for the distal-lake origin of the basal facies. It supposedly formed as the fill of drainless depressions in the distant foreland of the ice-sheet margin. By this process, the terrain was levelled and prepared for a gradual change from glaciolacustrine to glaciofluvial depositional regime.
\end{abstract}

\section{[Charakteristica und Ursprung saalezeitlicher glaziolacustriner bis glaziofluviatiler Folgen im Hümmling-Gebiet, NW Deutschland]}

Kurzfassung: Im Tiefland Nordwestdeutschlands sind von der saalezeitlichen Vereisung aufgebauten glazifluvialen Geestplatten und Stauchmoränen von flachen Niederungen umgeben. Im Untersuchungsgebiet im Hümmling besteht die Geestplatte aus hauptsächlich sandigen Schmelzwasserablagerungen die von Grundmoräne oder Blockbestreuung überdeckt sind. Diese Sanderfläche ist vom Haupt-Drenthe-Vorstoß abgelagert und danach beim weiteren Vorrücken des Eises überfahren worden. Die Schmelzwassersande bilden nach oben gröber werdende Sequenzen, die im Untersuchungsgebiet in drei Gruben aufgeschlossen sind.

Vom Liegenden zum Hangenden sind in den Aufschlüssen drei vom Wasser abgelagerte Fazies erkennbar: eine untere glazilimnische Fazies, eine Übergangsfazies und eine obere glazifluviale Fazies. Sofern sich keine erosiven Zwischenfälle ergeben haben, ist die aufwärtsgerichtete Veränderung von einer Fazies zur anderen ausgesprochen allmählich.

Dieser Artikel bringt Argumente dafür, daß die untere Fazies abgelagert worden sei in einer abflußlosen Senke,

\footnotetext{
*) Adress of the author: Dr. J. SCHWAN* \& DR. C. KASSE*, Faculty of Earth Sciences, Vrije Universiteit, De Boelelaan 1085, 1081 HV Amsterdam, The Netherlands
}

die sich im fernen Vorland des Inlandeises befand. Durch diesen Vorgang wurde das Gelände eingeebnet und vorbereitet auf eine allmähliche Änderung von glazilimnischen nach glazifluvialen Ablagerungsverhältnissen.

\section{Introduction}

In the lowland of northwest Germany, plateaus and hills consisting of Saalian glacial deposits and pushmoraines formed by the Saalian continental ice sheet are surrounded by flat and low-lying country. In German, these two major landform types are referred to as respectively "Geestplatten" and "Niederungen" (Figs. 1 and 2). The latter category represents a system of deep basins and valleys supposedly left behind by the Saalian ice and subsequently filled with mostly sandy sediment (German: Talsande).

In our study area in the Hümmling, the Geestplatte consists of considerable thicknesses of mainly sandy meltwater deposits with a cover of groundmoraine or till residue. In three exposures, the location of which is shown in Fig. 2, these sediments were available for sedimentologic analysis. When the information from the three sites is combined, the picture emerges of a coarsening-upward fluvioglacial sequence laid down and subsequently overridden by an advancing continental ice sheet.

This however, is a first-sight impression only and closer scrutiny shows that the fine-sandy basal part of the sequence should be of glaciolacustrine rather than glaciofluvial origin. This interpretation was not an obvious one as (i). classical glaciolacustrine features such as silty or clayey texture and varve-like structure are absent in the lower part of the sequence and (ii). the upward transition from finesandy lower unit to upper unit with gravelly-sand composition is gradational and, consequently, unsuggestive of any distinct break in depositional environment.

This paper gives arguments in support of the above interpretation and analyzes the environmental conditions under which glaciolacustrine to glaciofluvial successions may form.

\section{Geologic Setting}

Figures 1 and 2 show the generalized geomorphology of the study area and its wider surroundings. The corresponding stratigraphy is given in Fig. 3 .

Unit 1 is believed to represent a huge outwash plain built up during the older phase of Saalian glaciation (the Main Drenthe Advance) and subsequently overridden by the expanding ice sheet (SCHRÖDER 1978, CASPERs et al. 1995). Less clear is the origin of the 


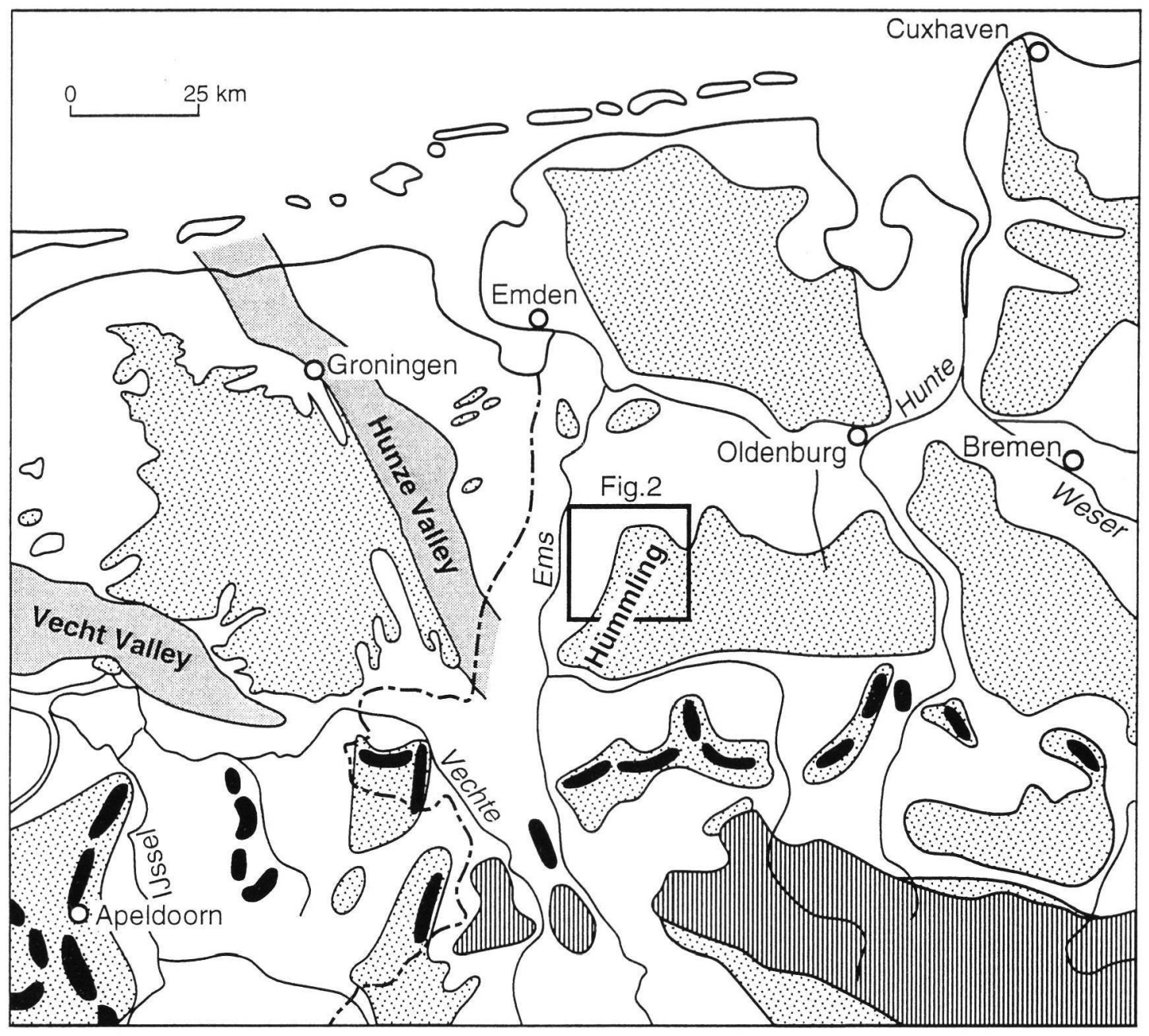

Plains and valleys with Weichselian periglacial or Holocene surface deposits

Plateaus, hills and hill-ridges consisting of Saalian glacial deposits and including glaciotectonic landforms pushed up by Saalian ice. These features are with or without a thin cover of Weichselian to Holocene aeolian sand

End moraines of Rehburger Phase

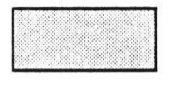

Buried Saalian valleys

Prequaternary uplands with or without a cover of Quaternary sediment

-. German - Dutch frontier

Fig. 1: Generalized geomorphology of northwest Germany and the northeastern Netherlands. Based on LiEDTKE (1973), Meyer (1983), ZaGwijn et al. (1985) and VAN DEN Berg \& BeETs (1987).

Abb. 1:Allgemeine Geomorphologie Nordwestdeutschlands und der nordöstlichen Niederlande. Nach LIEDTKE (1973), MEYER (1983), ZaGWIJN et al. (1985) und VAN DEN BERG \& BeEts (1987). 


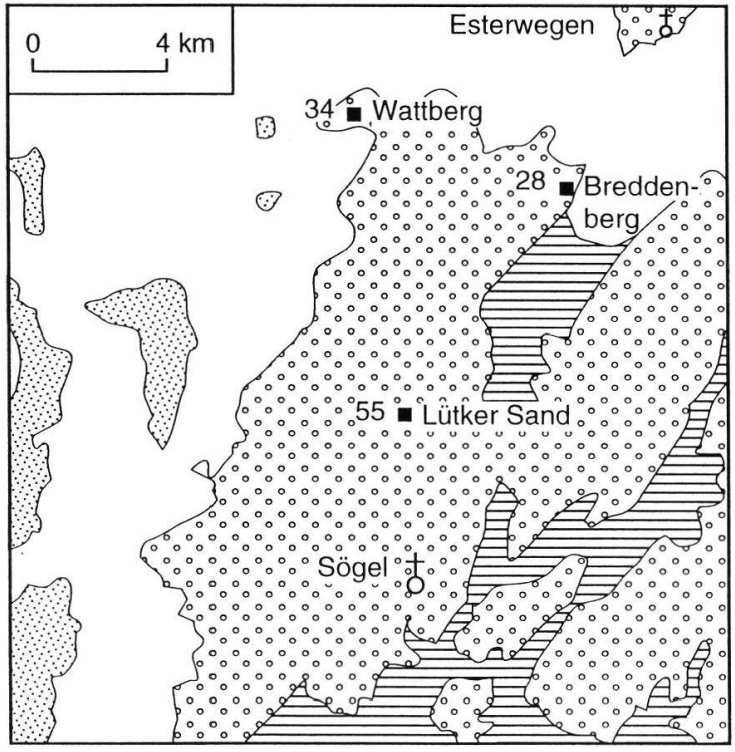

LEGEND

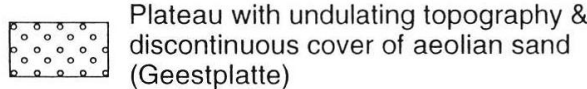

Zone of dunes \& aeolian sand sheets associated with river Ems

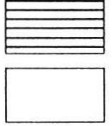

Gently sloping valley floors

Low-lying \& nearly flat plain (Niederung)

† Built-up area

28
Exposure site with height in $m$ above mean sea level

Fig. 2: Geomorphologic sketchmap of the study area with location of exposure sites.

Abb. 2: Grundriß der Geomorphologie des Untersuchungsgebietes mit Lage der Aufschlüsse.

deep and wide Talsand-filled basins that surround the Geestplateaus. Various authors (quoted by MEYER 1983) have suggested that at least part of them results from either glacial scouring or meltwater erosion when the ice sheet was retreating from the subject region. A similar ambiguity prevails with respect to the Hunze Valley, a buried valley in the subsoil of the northern Netherlands (Fig. 1). Whereas VAN DEN BERG \& BEETS (1987) interpreted both this feature and the fossil Vecht Valley as a lake-overflow channel, Bosch (1990) attributes the origin of the Hunze Valley to erosion by a narrow glacier tongue flowing in south-south eastern direction.

Unit 2 comprises (i). a generally thin layer of aeolian coversand that occurs on both plateaus and adjacent lowlands, and (ii). the Talsand that fills the basins. Essentially, the Talsand deposits in the area of concern consist of Late Saalian, Eemian and Weichselian fluvial beds having a capping of windborne sand. Within this sediment type, organogenic intercalations are fairly common. It has been suggested that both localized fluvio-periglacial activity as well as regional deposition by perennial or seasonal rivers contributed to the buildup of the subject unit (BoIGK et al. 1960, Duphorn et al. 1973, Meyer 1983).

Unit 3 consists of three subunits, viz. a podsolic soil marking the top of the Pleistocene plateau-sediments, a raised-bog peat that covers the Talsand north of the Geestplateau and, lastly, aeolian dunes that occur scattered in the study area.

\section{The observation sites}

Measured sections, lacquer peels and directional data were compiled in the three sandpits Breddenberg,
Lütker Sand and Wattberg (Fig. 2). With respect to these exposures, the following comments are given: 1. SCHRÖDER (1978) has suggested that the site Lütker Sand might represent an inlier of Elsterian age which is projecting through the strata of the Saalian outwash plain. Natural outcrops of Elsterian sediment occur only $55 \mathrm{~km}$ west of the Hümmling in Drenthe in The Netherlands (Ter WeE 1979, Bosch 1990) and this would seem to be in support of the above interpretation. The stratigraphical relationships assumed by SCHRÖDER (1978, his pages $81-85)$ are based on the shallower exposure-depths of his time. However, the present condition of sandpit Lütker Sand unequivocally shows that the "Sockelsand" is older than the "Sande und Kiese" with the reverse being the principal argument in favour of an Elsterian age. Consequently, the sediments of all three investigated sites are supposed to have been laid down during the same period, i. e. during the Main Drenthe Advance of the Saalian Stage.

2. The exposures consist of sediments that were overridden by the advancing ice sheet which had previously deposited them. The first halt of this ice sheet occurs well to the south of the Hümmling and is marked by the endmoraines of the Rehburger Phase (Fig. 1). In the study area itself, glaciotectonic deformation of the meltwater deposits is generally shallow and mild only. Because of the large size of the exposures, sections that had remained altogether free of distortion could be selected for sedimentologic analysis. A minor feature conceivably due to the stress exerted by an overriding ice sheet is the blurring or partial obliteration of structure found here and there in fine-grained layers. This could be a re- 


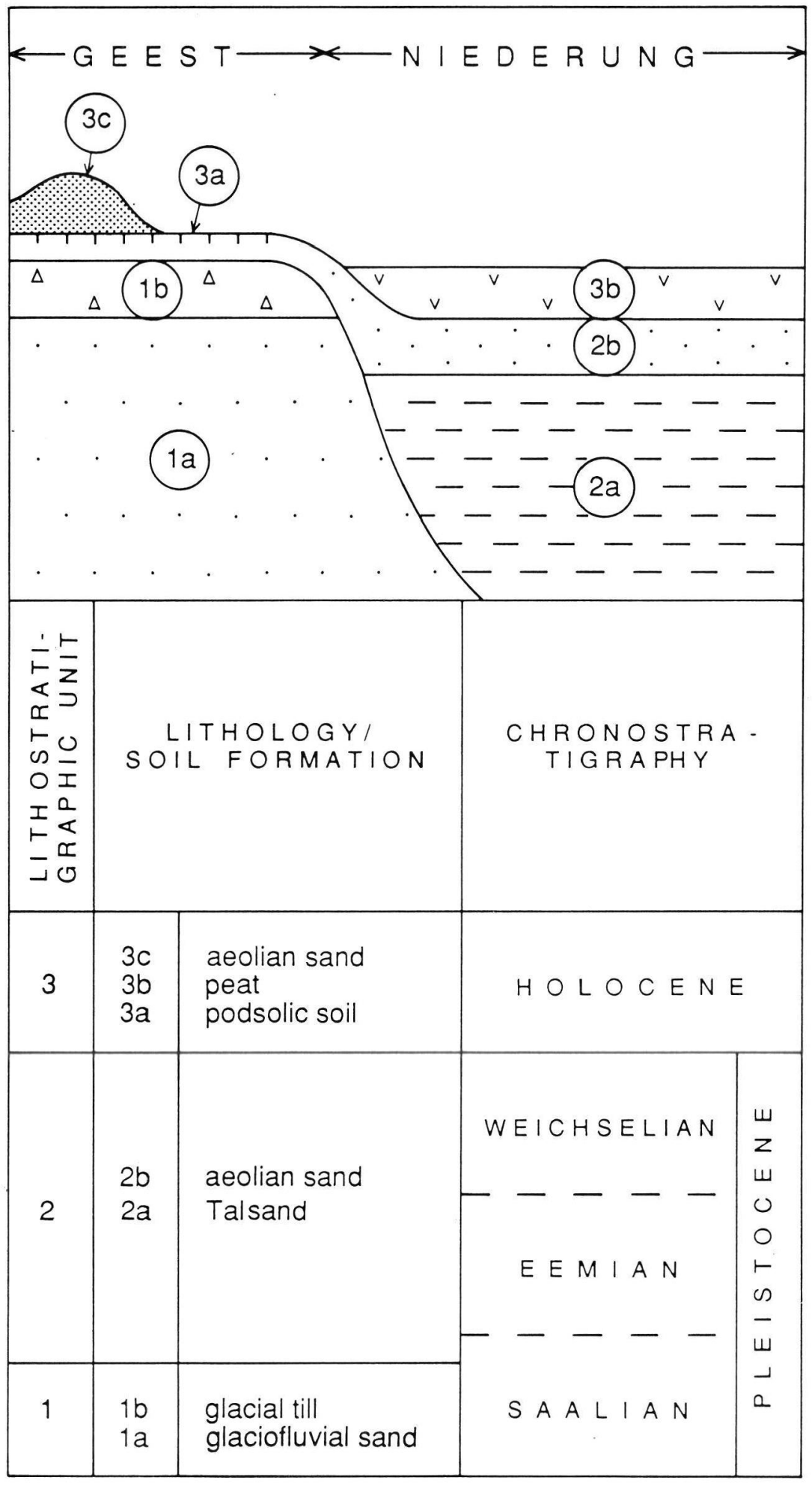

Fig. 3: Stratigraphy of the Hümmling study area. Abb. 3: Stratigraphie des Untersuchungsgebietes. sult of excessive porewater-pressure and the liquefaction associated with it.

\section{Facies subdivision}

In the sediments exposed at sites Breddenberg, Lütker Sand and Wattberg four waterlaid and two glacigenic facies have been distinguished (Figs. 4-9).

The waterlaid facies

The diagnostic features of the four waterlaid facies $\mathrm{A}, \mathrm{B}, \mathrm{C} 1$ and $\mathrm{C} 2$ are given in Table 1. Combination of the measured sections shows that the succession of the waterlaid facies A, B and $\mathrm{C} 1$ or $\mathrm{C} 2$ represents a coarsening-upward sequence. Unless erosion has interfered, the transition from one facies to the next is markedly gradational. But for the fact that in our case a change from glaciolacustrine to glaciofluvial environment is involved, successions of this type are common in Geestplateaus; in German they are referred to as Vorschüttsande, i. e. sands laid down by an advancing ice sheet (EHLERs \& Grube 1983).

Facies A. Facies A is characterized by both the alternation of planebedded and ripplelaminated sets and a texture ranging from silt to medium sand (Fig. 10). This facies is supposed to have formed by the discharge of sediment-laden meltwater into a distal 


\section{SEDIMENTOLOGIC LEGEND}

$1=$ Height above mean sea level in $\mathrm{m}$

$2=$ Facies types:
A = Lacustrine facies
$\mathrm{B}=$ Transitional facies
$\mathrm{C} 1, \mathrm{C} 2$ = Glaciofluvial facies
D1,D2 = Glacigenic facies

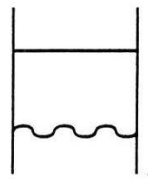

Gradational facies contact

Sharp or erosive facies contact

$3=$ Graphic log :

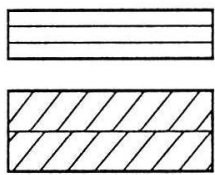

planebed lamination

cross-bedding

$\lambda$
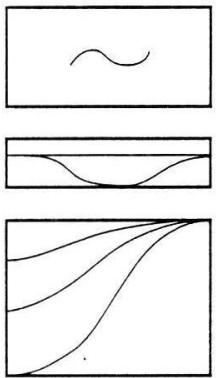

channel fill ; mid-channel depth $>2 \mathrm{~m}$

alternation of thin layers with ripple-foreset

$x$-lamination and planebed lamination

channel fill ; mid-channel depth $<1 \mathrm{~m}$

planar $\mathrm{x}$-lamination, trough $\mathrm{x}$-lamination or climbing-ripple $x$-lamination

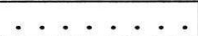

single graded bed or succession of several graded beds

channel with graded fill

single-grain string of gravels in matrix of sand

residue of weathered till

ground moraine
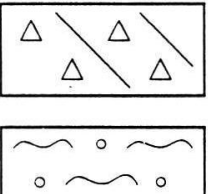

brecciated gravelly sand 


\section{SEDIMENTOLOGIC LEGEND (CON'D)}

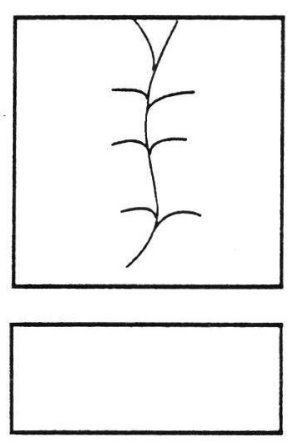

frost crack

no information

$4=$ Special features :

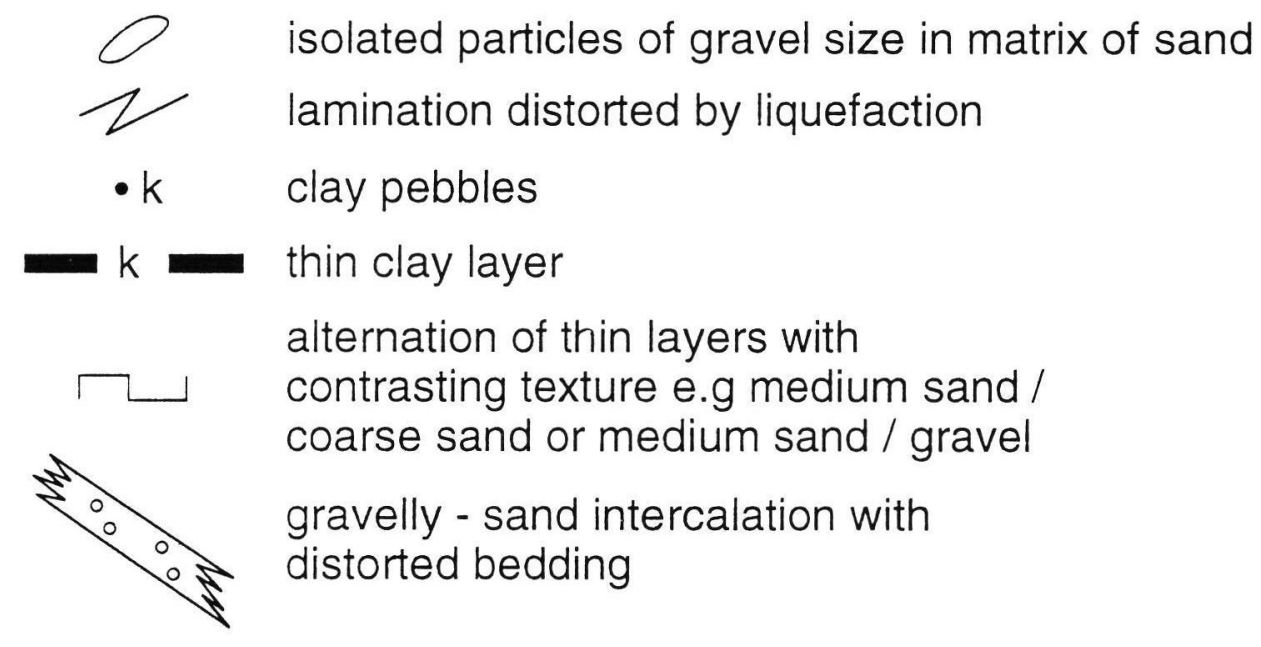

$5=$ Texture of waterlaid units :

$$
\begin{aligned}
\mathrm{Si}= & \text { silt } \\
\mathrm{fS}= & \text { fine sand } \\
\mathrm{mS}= & \text { medium sand } \\
\mathrm{cS}= & \text { coarse sand } \\
\mathrm{gS}= & \text { gravelly sand with gravel }- \text { layers in } \\
& \text { sandy matrix constituting at least } \\
& 10 \% \text { by volume }
\end{aligned}
$$




\section{BREDDENBERG}

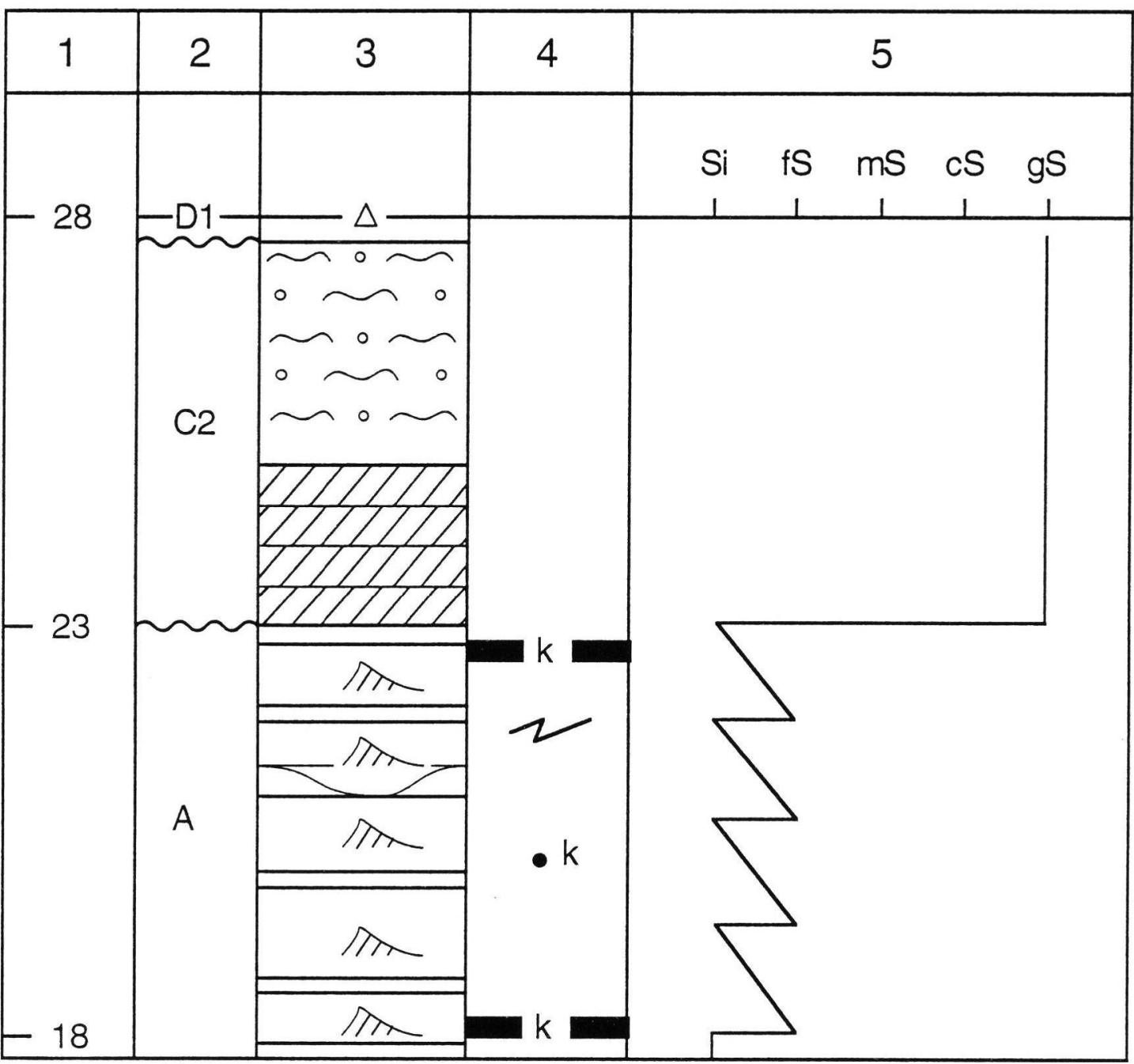

Fig. 0: Sedimentologic log of site Breddenberg.

Abb. 6: Sedimentologischer Profilschnitt des Aufschlusses Breddenberg.

lake, i. e. into a body of standing water located away from the ice-sheet margin (cf. SMITH and AsHLEY 1985). Accordingly, the successions of the two types of sets are regarded as incomplete, small-scale turbidites in which only the parallel-laminated division $\mathrm{B}$ and the current-rippled division $\mathrm{C}$ of the classical sequence of Bouma (1962) are represented. Between cycles, the thickness ratio of the two components shows considerable fluctuation and this suggests that the rhythmicity should be attributed to weatherdependent rather than seasonal discharge-variations.

An often applied criterion for the identification of lake deposits is the presence of silty and clayey beds. Apart from a few thin clay drapes and clay pebbles, this characteristic is lacking in facies A. Both the relatively elevated glauconite, mica and metamorphicmineral contents and the occurrence of lignite fragments indicate that facies A (as well as the other waterlaid facies) derive, to a large part, from the Presaalian Pleistocene and Tertiary subsoil of northwest Germany (e.g. Krook \& Schwan 1994). In the proximity of the German-Dutch border, these source beds have a mainly sandy composition (TeR WEE 1979 , Bosch 1990) and this should be the reason why in the lacustrine facies A a clayey component is practically absent.

Meyer (1982), Ehiers et al. (1984) and Ehlers (1994) discuss glaciolacustrine strata in sandur deposits that may well be coeval with our facies A. They occur 
LUUTKER SAND

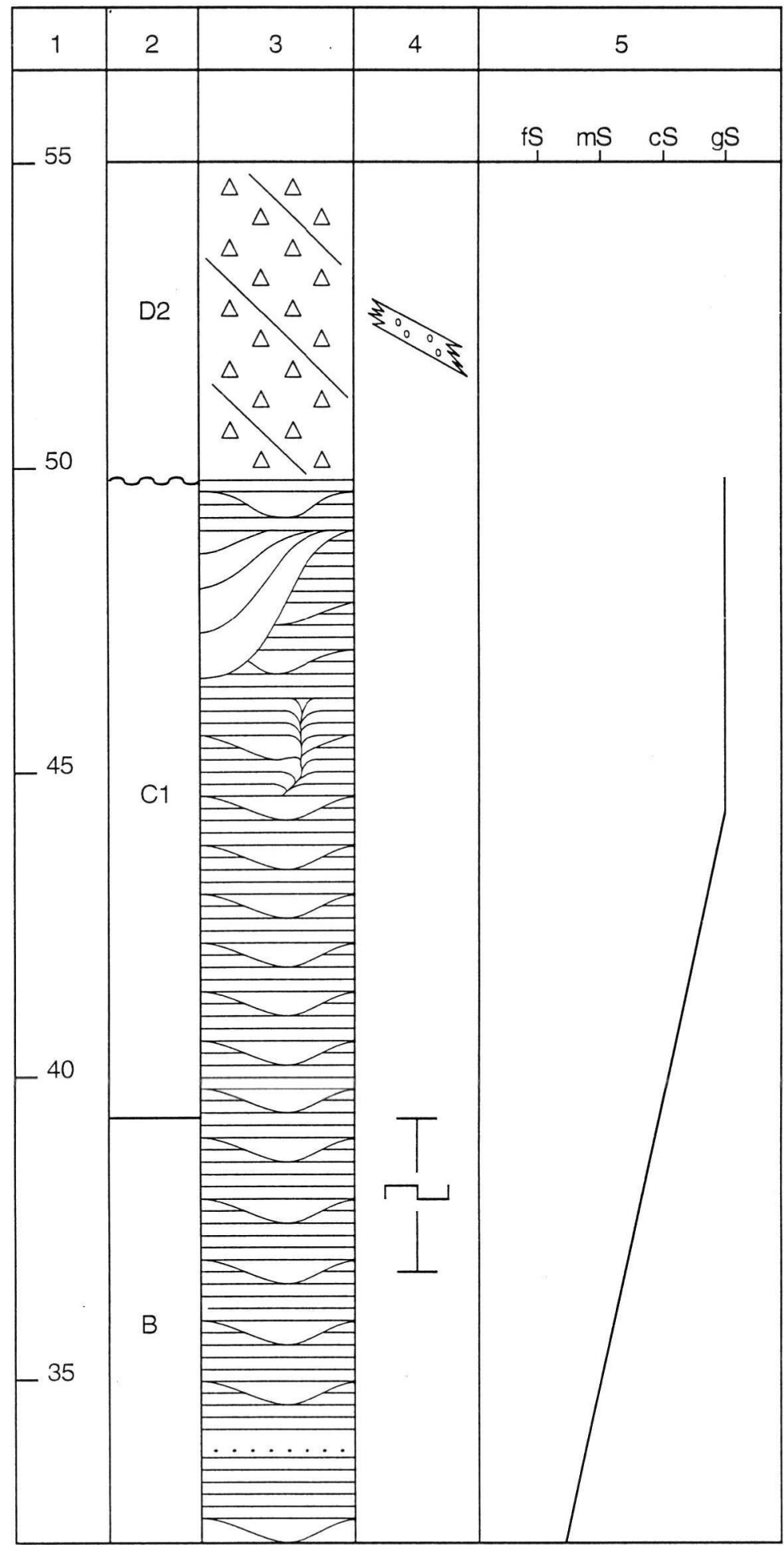

Fig. 7: Sedimentologic log of site Lütker Sand.

Abb. 7: Sedimentologischer Profilschnitt des Aufschlusses Lütker Sand. some $170 \mathrm{~km}$ northeast of the Hümmling in a Geestplateau south of the Elbe-estuary and consist of well-sorted fine sands having an average thickness of $10 \mathrm{~m}$. Sediments of this type, called Beckensande in German, supposedly were formed during the earliest part of the Saalian glaciation and their paleocurrent data are dominated by flow in northwestern to northern directions. Following the just-mentioned authors, these "basin sands" were laid down in huge shallow depressions occupying a distal position with respect to the ice-sheet margin or, alternatively, they might have been left behind by large braided-river systems.

Facies $B$. Regarding texture and structure facies B holds an intermediate position between facies $\mathrm{A}$ and $\mathrm{C} 1$ which underlie respectively overlie it. When facies B is distinguished from its counterparts on the basis of grainsize composition, there is not a unique type of structure to match. Depending on location we find predominance of either turbiditic couplets or channel fills in a planebedded matrix. Since the subject facies cannot be unequivocally tied to a specific depositional environment, it must be considered a transitional facies. Its significance is that it demonstrates the gradualness of the change from glaciolacustrine to glaciofluvial regime.

Facies $\mathrm{C} 1$ and $\mathrm{C} 2$. Facies $\mathrm{C} 1$ and $\mathrm{C} 2$ are two fluvioglacial facies having in common a gravelly-sand texture. The first facies consists of shallow channel fills with widths of up to 8 $\mathrm{m}$ and depths not exceeding 80 $\mathrm{cm}$ in a matrix of planebedded sand (Fig. 11). It probably represents a sheetflood deposit associated with an alluvial fan. The second facies is characterized by planar cross-bedding 
WATTBERG 1

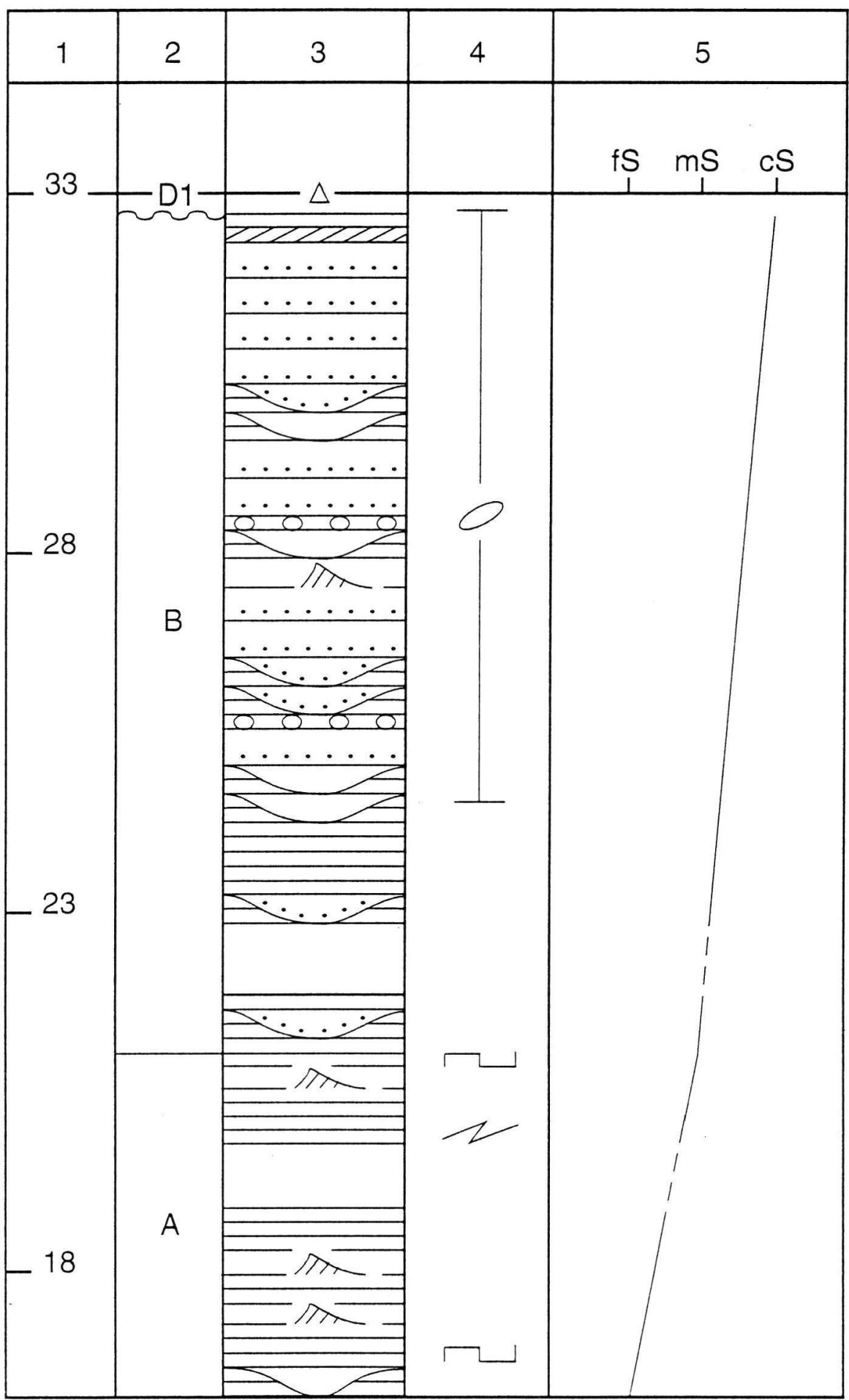

Fig. 8: Sedimentologic log of site Wattberg, section 1 Abb. 8: Sedimentologischer Profilschnitt 1 des Aufschlusses Wattberg. which may have formed in bars of

a braided river (Miall 1977). Facies $\mathrm{C} 2$ was found at site Breddenberg (Figs. 6 and 12) where a part of it suffered deformation or brecciation by ice push. The river course which deposited it apparently cut down deeply into the substrata as is evidenced by an abrupt textural break at the base of the facies under consideration

The glacigenic facies

Facies D1 is a residue of scattered erratics on the groundsurface which has been left over from weathering and washing of facies D2, the original groundmoraine. Facies D 2 is a subglacial till with loamy texture, crude stratification and an intercalation of gravelly sand. In the study area, this facies only occurs in natural hollows in the groundsurface where is was sheltered from Postsaalian weathering and erosion.

\section{Directional data}

The paleocurrent directions that 
WATTBERG 2

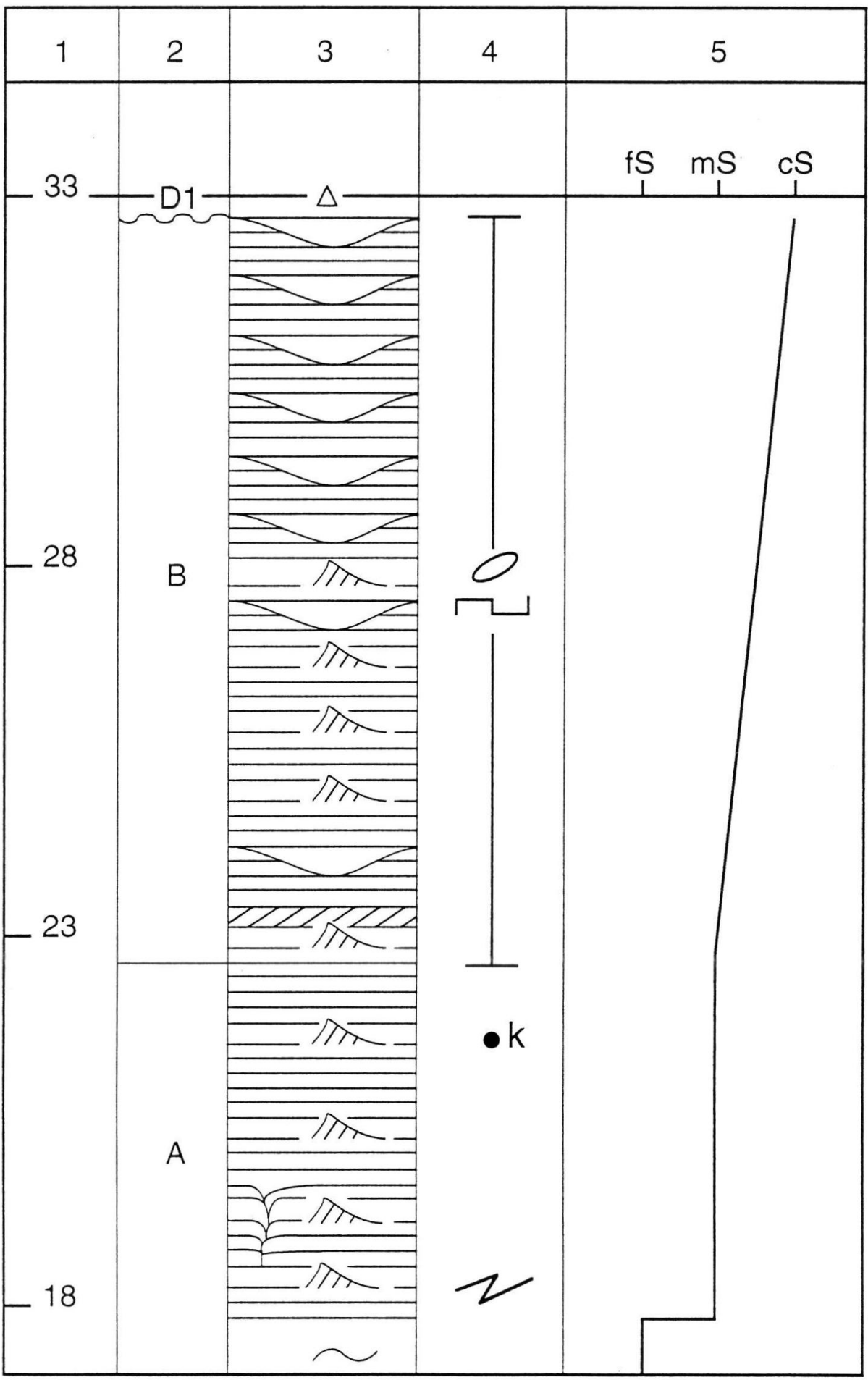

Fig. 9: Sedimentologic log of site Wattberg, section 2.

Abb. 9: Sedimentologischer Profilschnitt 2 des Aufschlusses Wattberg. were measured in the three exposures are given in Fig. 13. Included in this figure are readings from two now derelict sandpits in the immediate vicinity of site Lütker Sand. These data are a conversion of material compiled by S C H R Ö D E R (1978) and should compensate for the lack of information on exposure Lütker Sand itself. In the justmentioned sandpit structures suitable for measuring paleocurrent directions are hard to find. Shallow channel fills in a matrix of plan e b e d d ed sand are the prevailing type of sedimentary structure. With respect to these features it was found that they (i). occur in equal frequency in mutually perpendicular pit faces and (ii). are mostly of the types A and $\mathrm{B}$ of Fig. 14 and exceptionally of type $C$ of the sa- 


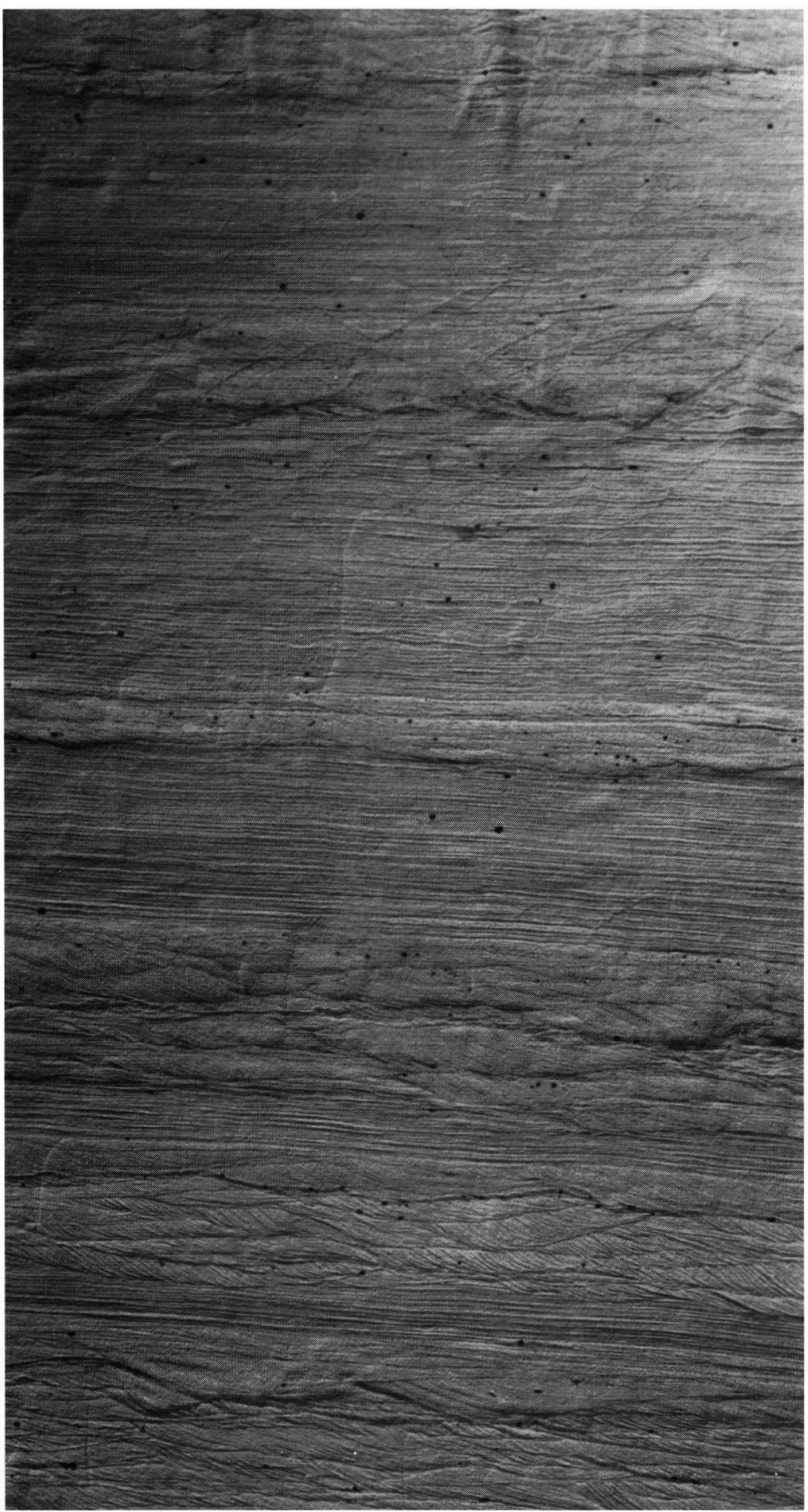

Fig. 10: Alternation of planebedded and ripple-laminated sets in incomplete turbidites of glaciolacustrine facies A. Scattered black mottles are lignite fragments. Lacquer peel from exposure Wattberg. Length of profile $=125 \mathrm{~cm}$.

Abb. 10: Abwechslung von Parallelschichtung und Rippelschichtung in unvollständig ausgebildeten Turbiditen der glazilimnischen Fazies A. Vereinzelte schwarze Flitter sind Braunkohlstückchen. Lackfilm aus Aufschluß Wattberg. Länge des Profils $=125 \mathrm{~cm}$. me figure. The fill of the first two types might be interpreted as either a lateralaccretion structure or a microdelta. Current flow would have been parallel to the channel axis in the first case but perpendicular to it in the second case. Thus, there are ambiguities relating both to the planform of the channels and the direction of the flows that filled them with sediment.

Two clusters of paleocurrent directions can be distinguished in Fig. 13: one in the sector SE to SSE and the other one in the sector $\mathrm{W}$ to WNW. From the bottom histogram of Fig. 13 it might be inferred that this result merely represents the dispersion inherent to the data in question. Alternatively, the bipartition could be significant in the sense that the clusters correspond to two different streams of sediment-laden meltwater forming at the ice-sheet margin and dropping their load in a closed basin. The two streams may have either coexisted when a sufficient size of the lake permitted this or otherwise they succeeded each other due to time-dependent changes in the position of the ice-sheet margin. In the first case it must be assumed that the ice-sheet margin had a curved or irregular outline rendering possible the formation of meltwater streams with widely differing flow directions within the bounds of the lake. From the work of SCHRÖDER (1978) it is understood that this requirement was met during the Saalian glaciation of the Hümmling-area. 


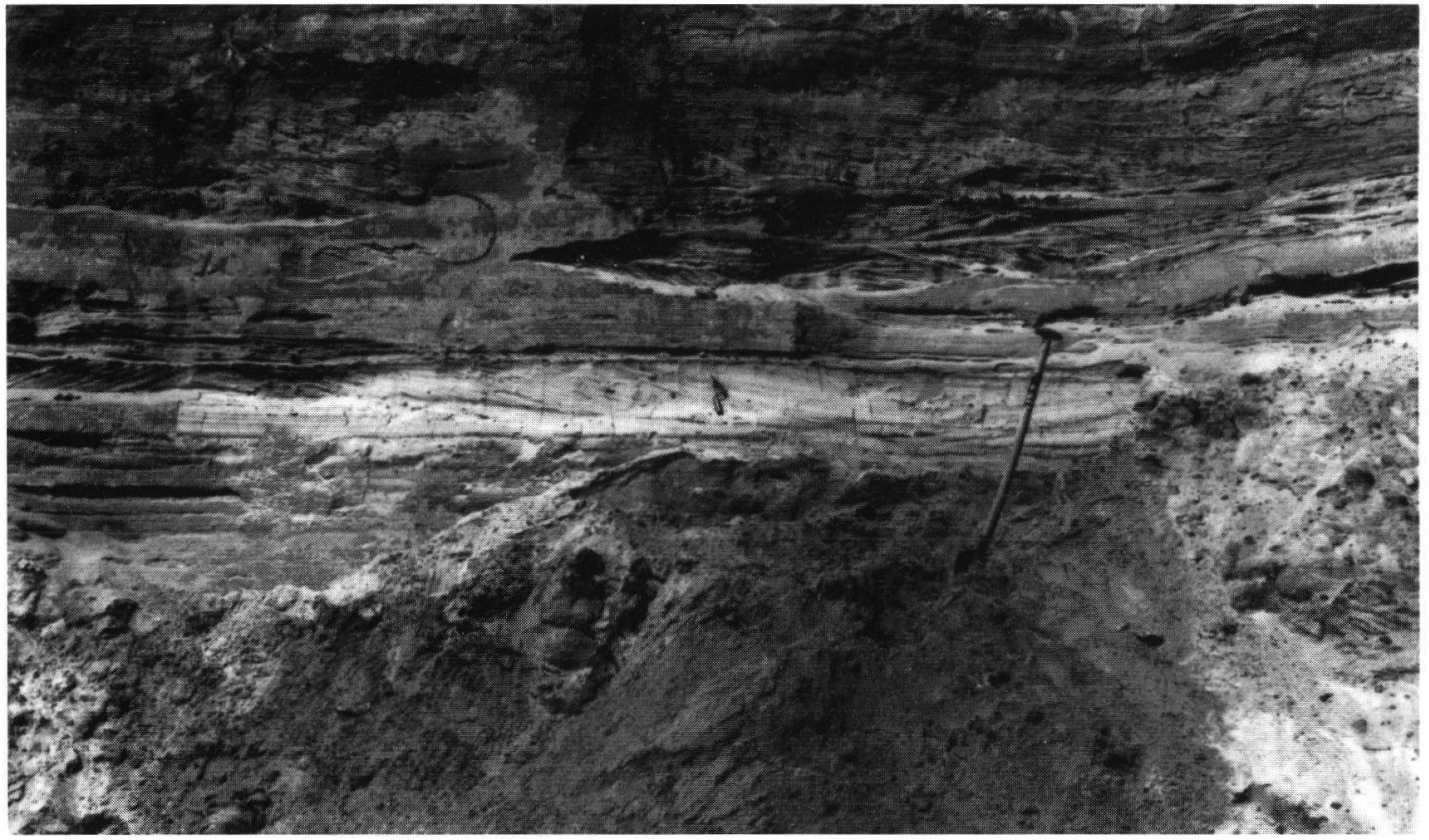

Fig. 11: Channel fills of glaciofluvial facies C1 in exposure Lütker Sand.

Abb. 11: Rinnenfüllungen der glazifluvialen Fazies C1 im Aufschluß Lütker Sand.

\section{Discussion}

Lacustrine deposition is a feature of wide occurrence in the glacial environment. In low-relief glacioterrestrial settings such as northern Europe and north America in Pleistocene times, huge lakes came into being as a result of overdeepening by glacial erosion, isostatic depression of the proglacial landsurface or the damming of epicontinental seas by the advancing ice sheet (GiBBARD 1988; Dawson 1992; EYLES \& EYLES 1992: EHLERS 1994). Other, smaller-scale events conducive to the ponding of meltwater were the damming of river valleys by the ice-sheet and the formation of tunnel valleys (EHLers \& LINKE 1989; EHLERS 1994) and glacial basins (DE Gans et al. 1987). In order to relate our glaciolacustrine to glaciofluvial succession to one or more of the above processes, the following hypothesis is proposed to account for its genesis:

In the early stages of Saalian glaciation, the study area occupied a distal position with respect to the ice-sheet margin and its ground surface was at a considerably lower level than it is now. It may be expected that the fine-grained margin of the incipient sandur preferentially filled drainless depressions that happened to be present in the distant foreland. This would result in a general levelling of the terrain and concomitant gradual change from lacustrine to fluvial regime. Lake deposits so formed would be thin, discontinuous and restricted to the early phase of a glaciation event.
The process under consideration depends on the presence of closed depressions, preferably of large size, in the foreland of the continental ice sheet. It is suggested that, at the onset of Saalian glaciation, this type of relief was represented in northwestern Germany by at least two different land forms.

In the first place there must have existed a Presaalian drainage pattern directed towards the North Sea and having an overall SE to NW or S to N orientation. With the advance of the continental ice sheet this system became blocked from the north and this provided traps for sediment-laden meltwater.

Secondly, the Elsterian ice sheet had left behind a system of wide and deep tunnel valleys in the subject area. It is imaginable that the generally north-south trending topography so created did survive through Holsteinian and preglacial Saalian times and expressed itself in the form of large, elongate depressions. Naturally, their original depth would not have been retained but the present assumption is that Postelsterian deposition did not fully level them either.

\section{Conclusions}

1. The sandy meltwater deposits exposed in the study area in northwestern Germany were laid down during the Main Drenthe Advance of the Saalian glaciation (= Older Saalian Glaciation) and represent a glaciolacustrine to glaciofluvial succession with coarsening-upward trend.

2. Stacks of incomplete, small-scale turbidites testify 
Table 1: Characteristics of waterlaid facies

Tabelle 1: Merkmale der vom Wasser abgelagerten Fazies.

\begin{tabular}{|c|c|c|c|c|c|}
\hline Facies & \multicolumn{2}{|c|}{ Texture } & \multicolumn{2}{|l|}{ Sorting } & $\begin{array}{l}\text { Facies - } \\
\text { contacts }\end{array}$ \\
\hline $\mathrm{C} 1, \mathrm{C} 2$ & $\begin{array}{l}\text { Coarse sand - } \\
\text { gravelly sand. } \\
\text { Size of gravels } \\
\text { up to } 5 \mathrm{~cm}\end{array}$ & \multirow{3}{*}{ 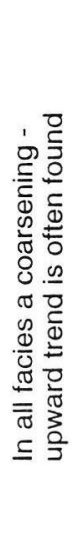 } & $\begin{array}{l}\text { Facies C2: alternation } \\
\text { of gravelly \& sandy } \\
\text { foreset beds } \\
\text { Facies C1: gravelly channel } \\
\text { fills in matrix of sand }\end{array}$ & \multirow{3}{*}{ 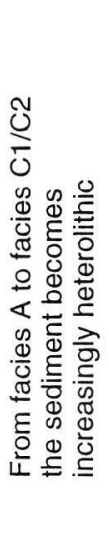 } & \multirow{3}{*}{ 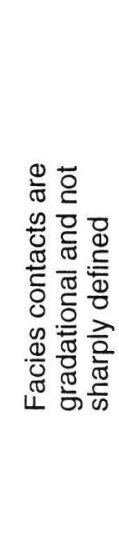 } \\
\hline B & $\begin{array}{l}\text { Fine sand - } \\
\text { coarse sand }\end{array}$ & & $\begin{array}{l}\text { Alternation of thin layers } \\
\text { of coarse, medium \& } \\
\text { fine sand with isolated } \\
\text { occurrences of gravel - } \\
\text { sized particles }\end{array}$ & & \\
\hline A & $\begin{array}{l}\text { Silt - medium } \\
\text { sand }\end{array}$ & & $\begin{array}{l}\text { Either homogeneous } \\
\text { texture or multiple } \\
\text { grading in fine sand } \\
\text { to silt range }\end{array}$ & & \\
\hline
\end{tabular}

Table 1: Characteristics of waterlaid facies (cont'd)

Tabelle 1: Merkmale der vom Wasser abgelagerten Fazies (Fortsetzung).

\begin{tabular}{|c|l|l|l|}
\hline Facies & \multicolumn{1}{|c|}{ Dominant structure } & \multicolumn{2}{|c|}{ Other features } \\
\hline C1,C2 & $\begin{array}{l}\text { Facies C2: Cross - bedded sets } \\
\text { with high gravel - content } \\
\text { (Fig. 12) } \\
\text { Facies C1: Frequent occurrence } \\
\text { of channel fills in matrix } \\
\text { of planebedded sand (Fig. 11) }\end{array}$ & $\begin{array}{l}\text { Facies C2 is partly brecciated or glaciotectonically } \\
\text { distorted }\end{array}$ & $\begin{array}{l}\text { Scattered dark } \\
\text { brown mottles } \\
\text { presumably being } \\
\text { lignite - fragments. } \\
\text { Relatively high } \\
\text { mica - content, in } \\
\text { particular in fine } \\
\text { fractions }\end{array}$ \\
\hline A & $\begin{array}{l}\text { Facies B is structurally } \\
\text { intermediate between facies A } \\
\text { and C1 }\end{array}$ & $\begin{array}{l}\text { Alternation of planebedding } \\
\text { and small - ripple lamination } \\
\text { (Fig. 10). Limited occurrence } \\
\text { of mainly small channel fills }\end{array}$ & $\begin{array}{l}\text { Occasional thin clay } \\
\text { layers and clay pebbles }\end{array}$ \\
\hline
\end{tabular}

to the distal-lake origin of the basal facies of the succession. Despite this mode of deposition, the basal facies hardly contains clay. This is due to the predominantly sandy composition of the Pleistocene and Tertiary sourcebeds of the meltwater deposits.

3 . In the meltwater deposits, two clusters of paleocurrent directions can be distinguished. The two clusters correspond to two streams of sediment-laden meltwater forming at the ice-sheet margin and depositing their load in a closed basin. The two streams either coexisted in a large lake or otherwise they succeeded each other as a result of changes in the position of the ice-sheet margin.

4. The basal facies formed as the fill of drainless depressions that happened to be present in the distant foreland of the ice-sheet margin. By this process, the terrain was levelled and prepared for a gradual change from lacustrine to fluvial depositional regime. The initial topography of the proglacial landsurface may have been shaped by both damming of preglacial rivercourses and Elsterian tunnel-valley formation.

\section{Acknowledgments}

We thank professor Dr. K.-D. Meyer for providing us with relevant information and Drs. K. Van Gijssel for interesting suggestions. 


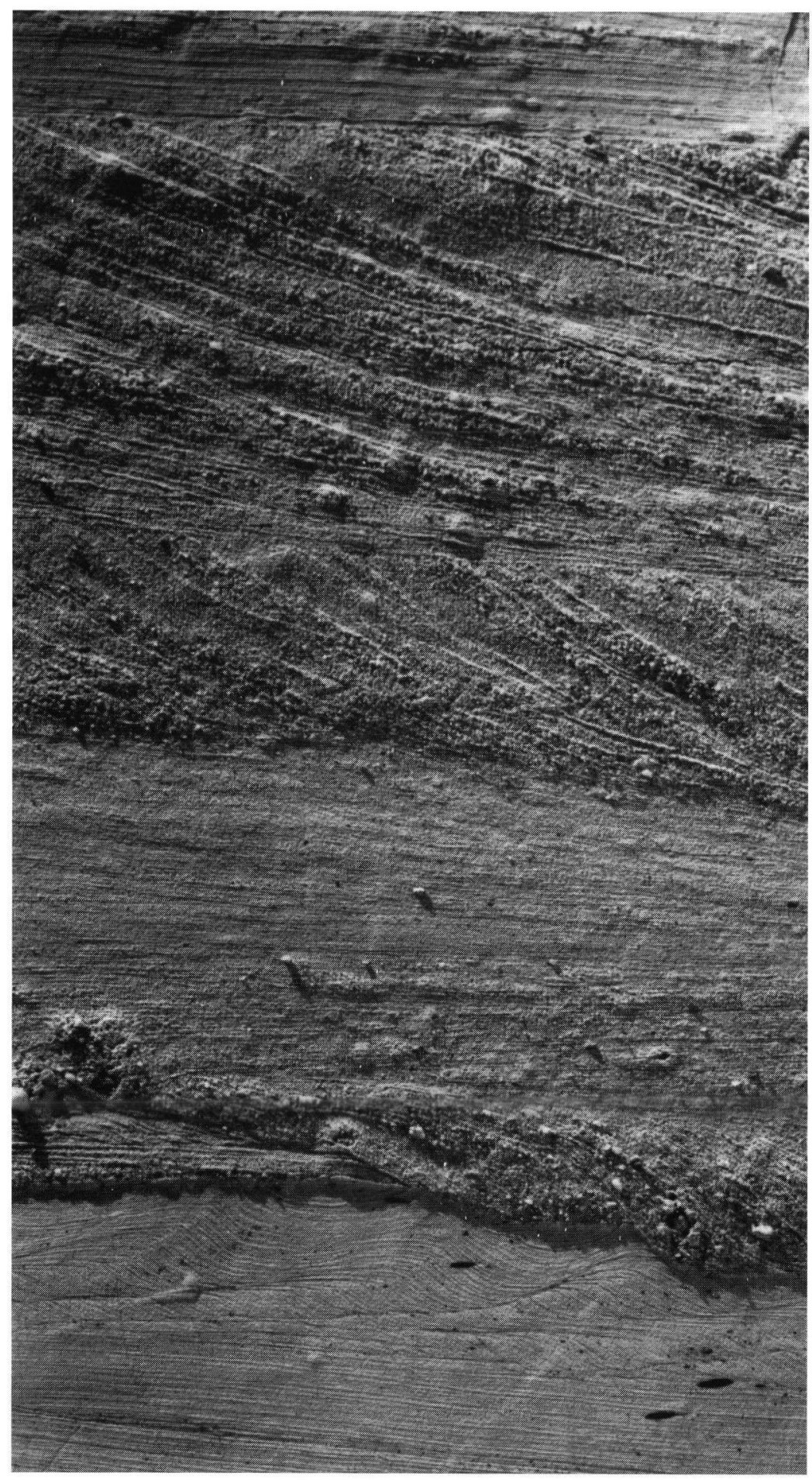

Fig. 12: Planar cross-bedded units of glaciofluvial facies C2 in upper half and sets with variable structure of intermediate facies B in lower half of lacquer peel from exposure Breddenberg. Length of profile $=125 \mathrm{~cm}$.

Abb. 12: Planparallele, kreuzgeschichtete Einheiten der glazifluvialen Fazies C2 in der oberen Hälfte und Schichte mit veränderlicher Struktur der Übergangsfazies B in der unteren Hälfte eines Lackfilmes aus Aufschluß Breddenberg. Länge des Profils $=125 \mathrm{~cm}$. 


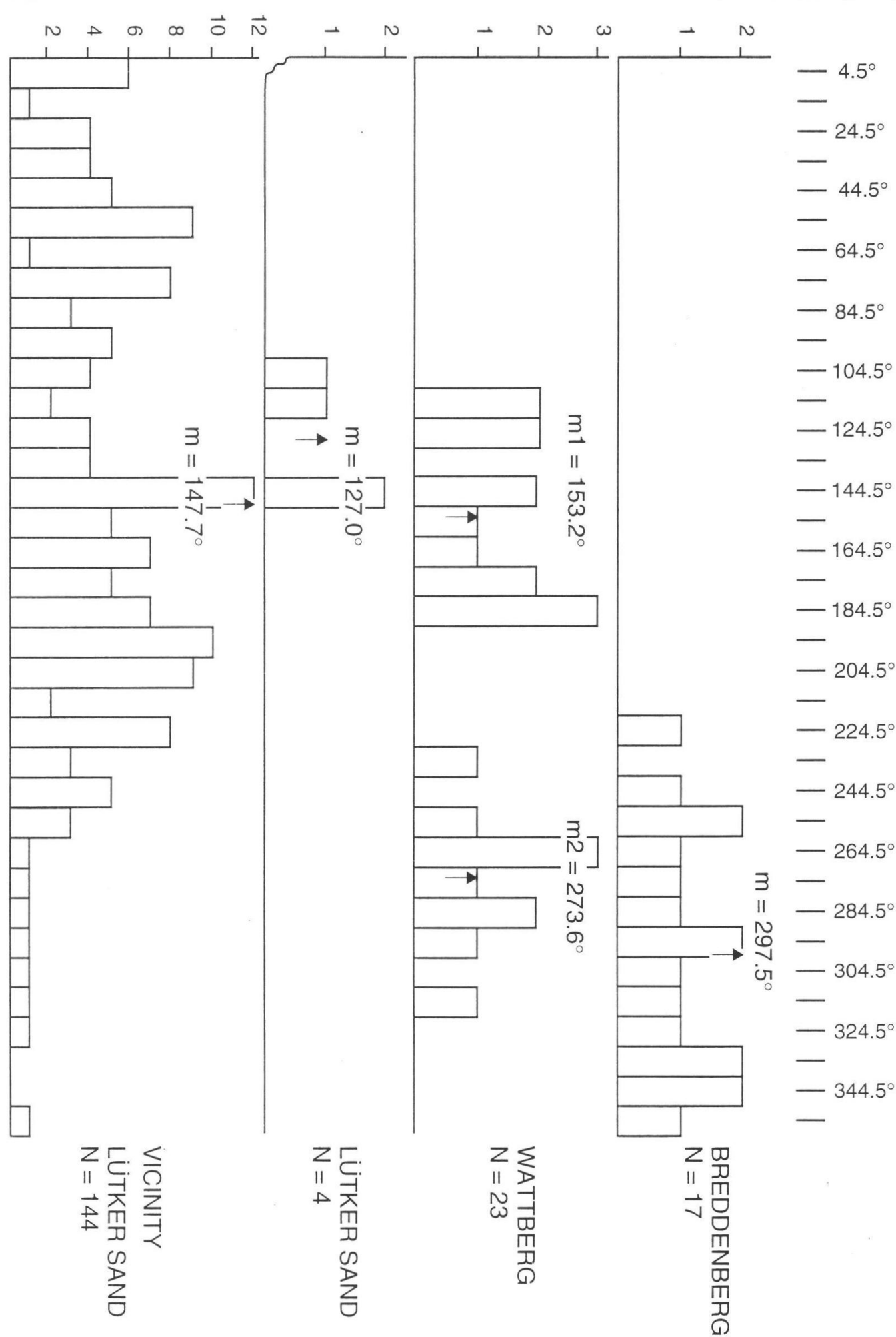

Fig. 13: Paleocurrent directions measured at four sites. The bottom histogram is a conversion of data compiled by ScHRÖDER (1978). $\mathrm{m}=$ mean paleocurrent direction.

Abb. 13: Schrägschichtungsmessungen an vier Stellen. Das unterste Histogramm ist hergestellt aus konvertierten Daten von SCHRÖDER (1978). $\mathrm{m}=$ Mittelwert der Aufschüttungsrichtung. 

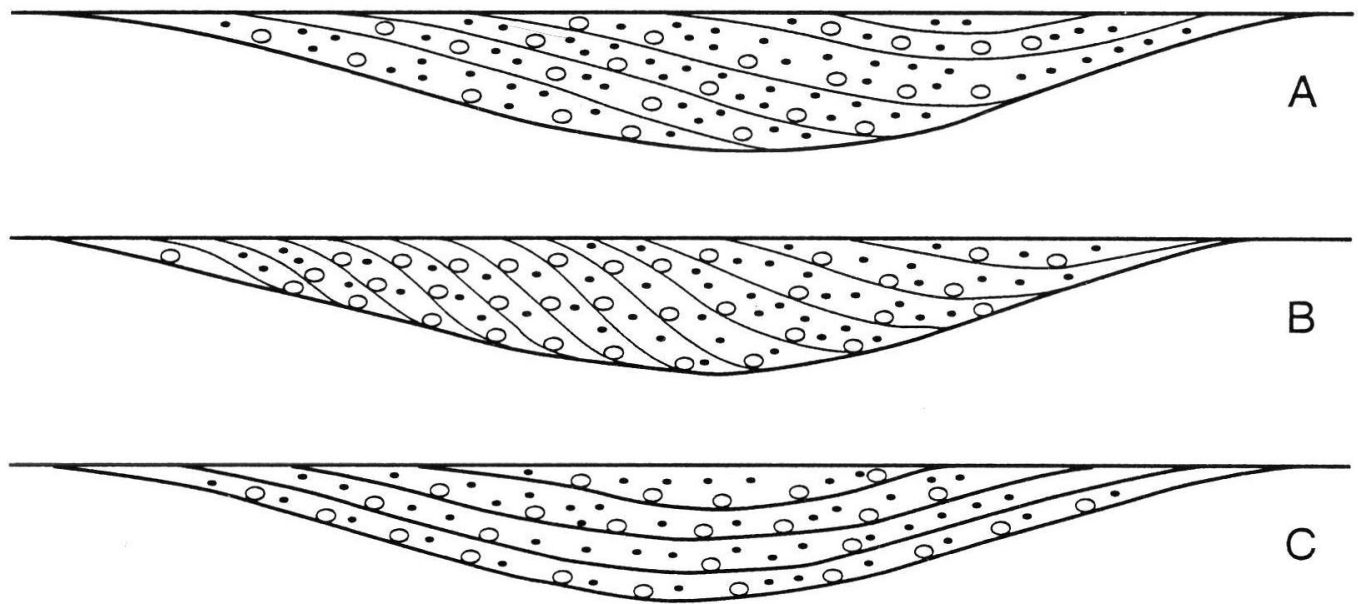

Fig. 14: Three types of channel fill in facies C1 at Lütker Sand. Types A and B are common and type C is rare. In types A and B flow may have been either from left to right (microdelta) or perpendicular to the page (lateral accretion).

Abb. 14: Drei Typen von Rinnenfüllungen in Fazies C1 in Lütker Sand. Typen A und B sind üblich und Typus C ist selten. In Typen A und B war die Strömung entweder von links nach rechts (Mikrodelta) oder senkrecht auf der Seite (seitwärtsgerichtete Aufschüttung).

\section{References}

Boigk, H., Dietz, C., Grahle, H.-O., Hoffmann, K., Hollstein, W., KÜHNe, F., Richter, W., SCHNEekloth, H., Wager, R. (1960): Zur Geologie des Emslandes. - Beih. Geol. Jb., 37; Hannover.

Bosch, J.H.A. (1990): Toelichtingen bij de geologische kaart van Nederland 1:50.000. Blad Assen West (12 W) en Blad Assen Oost (12 O). - Rijks Geologische Dienst; Haarlem.

Bouma, A.H. (1962): Sedimentology of some flysch deposits; Amsterdam.

Caspers, G., Jordan, H., Merkt, J., Meyer, K.-D., Müller, H. Streif, H. (1995): III. Niedersachsen. - In: BENDA, L. (Hrsg.): Das Quartär Deutschlands, Gebr. Borntraeger, 23-58; Berlin.

Dawson, A.G. (1992): Ice Age Earth; London.

De Gans, W., De Groot, T., ZWAan, H. (1987): The Amsterdam basin, a case study of a glacial basin in The Netherlands. - In: VAN DER Meer, J.J.M. (Hrsg): Tills and Glaciotectonics, A.A. Balkema, 205 - 216; Rotterdam.

Duphorn, K., Grube, F., Meyer, K.-D., Streif, H., Vinken, R. (1973): A. Area of the Scandinavian Glaciation, 1. Pleistocene and Holocene. - In: SCHÖNHALS, E. \& HUCKRIEDE, R. (Hrsg.): State of Research on the Quaternary of the Federal Republic of Germany. - Eiszeitalter u. Gegenwart, 23/24: 222 - 250; Öhringen/Württ.

EHLERS, J. (1994): Allgemeine und historische Quartärgeologie; Stuttgart.

- GRUBE, F. (1983): Meltwater deposits in north-west Germany. - In: EHLERS, J. (Hrsg.): Glacial Deposits in North-West Europe, A.A. Balkema, 249 - 256; Rotterdam.

- Linke, G. (1989): The origin of deep buried channels of Elsterian age in Northwest Germany. - J. of Quat. Sc., 4: 255 265; Chichester.

- Meyer, K.-D., Stephan, H.-J. (1984): Pre-Weichselian glaciations of North-West Europe. - Quat. Sci. Rev., 3: 1 - 40; Oxford.

EyLes, N., Eyles, C. H. (1992): 5. Glacial Depositional Systems. - In: WALKeR, R.G. \& James, N.P. (Hrsg.): Facies Models: response to sea level change, Geological Association of Canada, 73 - 100; St. John's, Newfoundland.
GibBaRD, P.L. (1988): The history of the great northwest European rivers during the past three million years. - Phil. Trans. R. Soc. Lond., B 318: 559 - 602; London.

KRоOK, L., Schwan, J. (1994): Sediment-petrologic characteristics of Saalian and Weichselian deposits in the Hümmling region, NW Germany. - Geologie en Mijnbouw, 72, 331 - 347; Utrecht.

LiEDTKE, H. (1973): Die nordischen Vereisungen in Mitteleuropa. Geologische Karte Maßstab 1:1.000.000; Berlin.

MEYER, K.-D. (1982): Erläuterungen zu Blatt Nr. 2524 Buxtehude, Geologische Karte von Niedersachsen 1:25.000. - Niedersächsisches Landesamt $\mathrm{f}$. Bodenforschung; Hannover.

- (1983): Zur Anlage der Urstromtäler in Niedersachsen. - Z. Geomorph. N.F., 27-2: 147 - 160; Berlin.

Miall, A.D. (1977): A Review of the Braided-River Depositional Environment. - Earth-Science Reviews, 13: 1 - 62; Amsterdam.

SCHRÖDER, E. (1978): Geomorphologische Untersuchungen im Hümmling. - Göttinger Geographische Abhandlungen, 70: 5 111; Göttingen.

Smith, N.D., Ashley, G.M. (1985): Chapter 4 Proglacial lacustrine environment. - In: AsHLEY, G.M. et al. (Hrsg.): Glacial sedimentary environments, Soc. of Economic Paleontologists and Mineralogists, 16: 135 - 216; Tulsa, OK

Ter WeE, M.W. (1979): Toelichtingen bij de geologische kaart van Nederland 1:50.000, Blad Emmen West (17 W) en Blad Emmen Oost (17 O). - Rijks Geologische Dienst; Haarlem.

VAN DEN BERG, M.W., BEETS, D.J. (1987): Saalian glacial deposits and morphology in The Netherlands. - In: VAN DER MEER, J.J.M. (Hrsg.): Tills and Glaciotectonics, A.A. Balkema, 235 - 251; Rotterdam.

Zagwijn, W.H., Beets, D.J., Van den Berg, M., Van Montfrans, H.M., Van Roojien, P. (1985): Atlas van Nederland, deel 13: Geologie. - Stichting Wetenschappelijke Atlas van Nederland; Den Haag.

Manuskript eingegangen am 13.05.1996 